\title{
BIOLOGICAL NITROGEN FIXATION AND ITS EFFECTS ON THE PHYSIOLOGICAL POTENTIAL OF COMMON BEAN SEEDS
}

Vitor Henrique Vaz Mondoํㄹ ${ }^{1}$ Enderson Petrônio de Brito Ferreira ${ }^{1}$, Nand Kumar Fageria' ${ }^{1}$; Marco Túlio Machado Costa ${ }^{2}$

${ }^{1}$ Embrapa Rice and Beans -E-mail: vitor.mondo@embrapa.br, enderson.ferreira@embrapa.br, nand.fageria@embrapa.br

${ }^{2}$ Universidade Federal de Goiás, E-mail: marcotulio_suk@hotmail.com

\section{ABSTRACT}

The aim of this study was to evaluate the effects of biological nitrogen fixation and its association with mineral sources of nitrogen in common bean seed physiological potential. Therefore, a field experiment was conducted from April to August 2012, using three common bean varieties ('BRS Requinte', 'BRS Notável' and 'Aporé'), which were grown and subjected to the following treatments: non-inoculated seeds, inoculated seeds, inoculated seeds $+50 \mathrm{~kg} \cdot \mathrm{ha}^{-1}$ of $\mathrm{N}$ and non-inoculated seed $+120 \mathrm{~kg} \mathrm{ha}^{-1}$ of N. The seeds were evaluated in Embrapa Rice and Beans seed analysis laboratory, by physiological tests of germination and seed vigor (first count of germination, accelerated aging, seedling length and electrical conductivity). It was concluded that the mineral nitrogen fertilization, for common bean crop, when associated with biological nitrogen fixation, may be reduced from high (120 kg.ha-1 of N) to low doses (50 kg.ha-1 of N). Such reduction does not affect seed physiological potential.

Keywords: Biological fixation, Rhizobium tropici, seed quality, Phaseolus vulgaris

\section{FIXAÇÃO BIOLÓGICA DE NITROGÊNIO E EFEITOS SOBRE O POTENCIAL FISIOLÓGICO DE SEMENTES DE FEIJÃO-COMUM}

\section{RESUMO}

O objetivo deste estudo foi avaliar os efeitos da fixação biológica de nitrogênio e sua associação com fontes minerais de nitrogênio no potencial fisiológico de sementes de feijãocomum. Para tanto, um experimento de campo foi realizado utilizando-se três cultivares de feijão, as quais foram semeadas e submetidas aos seguintes tratamentos: sementes não-inoculadas; sementes inoculadas; sementes inoculadas +50 kg.ha-1 de $\mathrm{N}$ e; sementes não-inoculadas +120 kg.ha-1 de N. As sementes colhidas foram avaliadas por meio de testes fisiológicos de germinação e vigor das sementes (primeira contagem de germinação, envelhecimento acelerado, comprimento 
de plântulas e condutividade elétrica). Verificou-se que a adubação nitrogenada mineral, na cultura do feijão-comum, quando associada à fixação biológica de nitrogênio, pode ser reduzida de alta (120 kg.ha-1 de N) para baixa dose (50 kg.ha-1 de N), tal redução não afeta o potencial fisiológico das sementes.

Palavras-chave: Fixação biológica, Rhizobium tropici, qualidade de sementes,Phaseolus vulgaris

INTRODUCTION

Mineral fertilizers are the main source of nitrogen $(\mathrm{N})$ applied to cultivated soils, followed closely by livestock manure (HOODA et al., 2000). Although, there are available other sources of $\mathrm{N}$ to the soil, being biological $\mathrm{N}$ fixation (BNF) in legume nodules the major one (ANDREWS et al., 2010; TIKHONOVICH \& PROVOROV, 2011; HIREL et al., 2011), and the most important $\mathrm{N}$-fixing agents are the symbiotic associations between crop legumes and bacteria of the family Rhizobiaceae (FUSTEC et al., 2010; LIU et al., 2011).

Rhizobium tropici is used in Brazil as inoculant in common bean (Phaseolus vulgaris L.), establishing symbiotic associations and resulting in spherical determinate nodules where $\mathrm{N}$ fixation process takes place. The improvement of this process in common bean grain yield with Rhizobium tropici seed inoculation has been reported by Pelegrin et al. (2009), however, the use of $\mathrm{N}$ fertilizer is still important to reach high yields under most agro-ecological conditions (FAGERIA et al., 2011).

The relation of seed physiological potential with soil fertilization has been constantly studied by seed scientists (ZUCARELI et al., 2011; GOMES-JÚNIOR \& SÁ, 2010; KIKUTI et al., 2007; 2006; CRUSCIOL et al., 2003; AMBROSANO et al., 1999), showing that germination normally is not influenced by soil fertilization. However, Carvalho \& Nakagawa (2000) consider that fertilization is one of the limiting factors for producing high quality seeds, just as Farinelli et al. (2006) who observed increases of germination percentage and seed vigor with applications of $\mathrm{N}$ in common bean fields.

The use of BNF in common bean has received incentives from Brazilian government and its application in the agriculture is increasing year by year. Considering this, there is an important question to be answered for seed production sector: Does biological nitrogen fixation affect common bean seed quality? Therefore 
this way, the present study aimed at understanding the effects of biological nitrogen fixation and the association with nitrogen fertilizer on the physiological potential common bean seeds.

\section{MATERIAL AND METHODS}

A field experiment was conducted at the Embrapa Rice and Beans experimental area in Santo Antônio de Goiás, State of Goiás, Brazil, from April to August of 2012. Three common bean varieties ('BRS Requinte', 'BRS Notável' and 'Aporé') were sowed in a randomized complete block design with three replications. The plots were composed by four five-meters planting rows spaced $0.45 \mathrm{~m}$, considering the central four meters of two central rows as evaluation area. Each plot received $100 \mathrm{~kg} \cdot \mathrm{ha}^{-1}$ of $\mathrm{P}_{2} \mathrm{O}_{5}$ and $100 \mathrm{~kg} \cdot \mathrm{ha}^{-1}$ of $\mathrm{K}_{2} \mathrm{O}$ as basal fertilizers in furrow at sowing, was irrigated when needed, and kept free from weeds, diseases and insects during cultivation cycle. The treatments were composed by thecombination of nitrogen mineral fertilization with urea and biological nitrogen fixation by three Rhizobium tropici strains: (T1) non-inoculated seeds $+0 \mathrm{~kg} \cdot \mathrm{ha}^{-1}$ of mineral $\mathrm{N}$ as control; (T2) inoculated-seeds with rhizobia strains $+0 \mathrm{~kg} \cdot \mathrm{ha}^{-1}$ of mineral $\mathrm{N}$; (T3) inoculated seeds with rhizobia strains +
$50 \mathrm{~kg} \cdot \mathrm{ha}^{-1}$ of mineral N ; and (T4) noninoculated seeds $+120 \mathrm{~kg} \cdot \mathrm{ha}^{-1}$ of mineral $\mathrm{N}$. For seed inoculation, a three strains mixture in the ratio of $1: 1: 1$ from Brazilian and CIAT Rhizobium tropici (SEMIA $4055=$ CIAT 899, SEMIA $4080=$ PRF 81, and SEMIA $4088=$ CPAC H12) were used as inoculants, and for mineral fertilization, half of the $\mathrm{N}$ was applied at sowing and remaining half was topdressed 35 days after sowing. The plots were handly harvested and threshed to avoid seed losses and mechanical damages. After that, seeds were sun dried until reaching $13 \%$ of moisture content and stored for seed quality assessment.

Seed assessment was conducted by the following tests:

Moisture content (MC): determined by oven drying two seed samples of $20 \mathrm{~g}$ from each seed lot at $105^{\circ} \mathrm{C} \pm 3^{\circ} \mathrm{C}$ for $24 \mathrm{~h}$, followed by weighing (Brasil, 2009), with results expressed as percentage.

Germination $(G)$ : carried out with four replicates of 50 seeds per lot in rolled paper towels. Seeds were uniformly distributed on two germination paper towels moistened with water to 2.5 times the dry paper weight and covered with another paper towel. The rolls were vertically placed in a dark germination chamber at $25 \pm 1{ }^{\circ} \mathrm{C}$. The percentage of normal seedlings was recorded 
on the fifth, for first count of germination evaluation ( $F C G$ ), and ninth day after sowing (BRASIL, 2009).

Accelerated aging (AA): performed with four replicates of 50 seeds per lot. The seeds were placed upon a screen inside transparent plastic boxes $(11.5 \times 11.5 \times 3.5$ $\mathrm{cm}$ ) and suspended over $40 \mathrm{~mL}$ of water. The boxes were placed in a germination chamber and maintained at $41 \pm 1^{\circ} \mathrm{C}$ for $72 \mathrm{~h}$ (Kappes et al., 2012). After the aging period, seeds were submitted to germination test, as described previously, and the normal seedlings were counted at the fifth day after sowing. The results were expressed as percentage of normal seedlings.

Seedling length (SL): determined using four replicates of 20 seeds each per seed lot. The test was conducted was previously described for germination test, however, for sowing, two lines of seeds were equally distributed six centimeters from the superior board of the paper roll and with the hilum headed upward for adequate seedling development and to avoid seedlings contact. In the seventh day after sowing, seedlings total length were measured and recorded.

Electrical conductivity (EC): determined using four replicates of 50 seeds each per seed lot. The samples had been previously weighed (0.1-g accuracy) and were placed in plastic containers $(200 \mathrm{~mL})$ with $75 \mathrm{~mL}$ of deionized water and kept at 25 ${ }^{\circ} \mathrm{C}$ for $24 \mathrm{~h}$ in a germination chamber. The electrical conductivity of the solution was determined using a Digimed DM-20 conductivity meter $\left(\mu \mathrm{S} . \mathrm{cm}^{-1} \cdot \mathrm{g}^{-1}\right)$ (Kappes et al., 2012).

All data were submitted to analysis of variance as a completely randomized design within each treatment or characterization test, and when $F$ values were significant, means were compared using Tukey's test ( $\mathrm{p} \leq 0.05)$.

\section{RESULTS AND DISCUSSION}

The results of moisture content (data not presented) showed no differences among samples before seed tests were applied. The mean moisture contents were $9.46 \%, 9.66 \%$ and $9.35 \%$ for 'BRS Requinte', 'BRS Notável' and 'Aporé' respectively, guaranteeing that this factor did not had influences on physiological potential assessment (Table 1). 
Table 1. Biological nitrogen fixation effects on seed physiological potential of 'BRS Requinte', 'BRS Notável' and 'Aporé' common bean varieties. G - Germination; AA - Accelerated aging; SL - Seedling length; EC - Electrical conductivity

\begin{tabular}{|c|c|c|c|c|c|}
\hline Treatment & $\mathrm{G}(\%)$ & $\mathrm{FGC}(\%)$ & $\mathrm{AA}(\%)$ & $\mathrm{SL}(\mathrm{mm})$ & $\mathrm{EC}$ \\
\hline
\end{tabular}

\section{BRS Requinte}

\begin{tabular}{lccccc}
\hline Control & $944^{\mathrm{ns}}$ & $88 \mathrm{~b}^{*}$ & $79^{\mathrm{ns}}$ & $165.1 \mathrm{bc}$ & $113.13^{\mathrm{ns}}$ \\
\hline Inoculant & 95 & $88 \mathrm{ab}$ & 84 & $153.4 \mathrm{c}$ & 113.02 \\
\hline $\begin{array}{l}\text { Inoculant }+\mathrm{N} \\
\left(50 \mathrm{~kg} \mathrm{ha}^{-1}\right)\end{array}$ & 98 & $94 \mathrm{ab}$ & 90 & $197.9 \mathrm{ab}$ & 88.48 \\
$\mathrm{~N}\left(120 \mathrm{~kg} \mathrm{ha}^{-1}\right)$ & 99 & $96 \mathrm{a}$ & 82 & $208.6 \mathrm{a}$ & 99.03 \\
\hline $\mathrm{CV}(\%)$ & 2.15 & 3.43 & 13.46 & 8.22 & 20.71 \\
\hline
\end{tabular}

\begin{tabular}{lccccc}
\hline & \multicolumn{5}{c}{ BRS Notável } \\
\hline Control & $89^{\mathrm{ns}}$ & $82^{\mathrm{ns}}$ & $80 \mathrm{ab}$ & $154.8^{\mathrm{ns}}$ & $107.74^{\mathrm{ns}}$ \\
\hline Inoculant & 90 & 77 & $73 \mathrm{~b}$ & 147.7 & 103.07 \\
\hline $\begin{array}{l}\text { Inoculant }+\mathrm{N} \\
\left(50 \mathrm{~kg} \mathrm{ha}^{-1}\right)\end{array}$ & 91 & 82 & $79 \mathrm{ab}$ & 130.5 & 105.03 \\
$\mathrm{~N}\left(120 \mathrm{~kg} \mathrm{ha}^{-1}\right)$ & 91 & 84 & $84 \mathrm{a}$ & 143.9 & 77.70 \\
\hline $\mathrm{CV}(\%)$ & 4.82 & 8.31 & 3.54 & 15.05 & 15.45 \\
\hline
\end{tabular}

\begin{tabular}{lccccc}
\hline \multicolumn{5}{c}{ Aporé } \\
\hline Control & $90^{\mathrm{ns}}$ & $82^{\mathrm{ns}}$ & $78^{\mathrm{ns}}$ & $145.9^{\mathrm{ns}}$ & $102.56^{\mathrm{ns}}$ \\
\hline Inoculant & 87 & 71 & 63 & 130.8 & 108.14 \\
\hline $\begin{array}{l}\text { Inoculant }+\mathrm{N} \\
\left(50 \mathrm{~kg} \mathrm{ha}^{-1}\right)\end{array}$ & 89 & 76 & 55 & 144.8 & 101.91 \\
$\mathrm{~N}\left(120 \mathrm{~kg} \mathrm{ha}^{-1}\right)$ & 94 & 87 & 76 & 163.3 & 87.67 \\
\hline $\mathrm{CV}(\%)$ & 3.21 & 8.23 & 17.49 & 9.46 & 19.94
\end{tabular}

* Means followed by same letter do not significantly differ according to Tukey's test $(\mathrm{p}<0.05) .{ }^{\text {ns }}$ Non-significant by $\mathrm{F}$ test $(\mathrm{P}<0.05)$. CV: coefficient of variance. 
The results were considered very similar among varieties, showing consistency and independence from genotypes. Germination percentage and electrical conductivity were similar for all treatments independently of genotype, showing that the results are reproducible in the other varieties. For all other tests, first count of germination, accelerated aging and seedling length data were not significant among treatments for two of three varieties. Those findings are similar to the ones found in literature (ZUCARELI et al., 2011; GOMES-JÚNIOR \& SÁ, 2010; KIKUTI et al., 2007; 2006; CRUSCIOL et al., 2003; AMBROSANO et al., 1999) showing no influences of mineral fertilization on seed physiological potential. However, for first count of germination and seed length in 'BRS Requinte' variety, and for accelerated aging in 'BRS Notável' variety, differences were found. Based on the results obtained, it was observed that control and inoculant treatments were, in general, inferior from standard $\mathrm{N}$ fertilization (120 $\left.\mathrm{kg} \cdot \mathrm{ha}^{-1}\right)$. Similar results were found by Kikuti et al. (2006), Farinelli et al. (2006) and Toledo et al. (2009), who did find positive effects of $\mathrm{N}$ fertilization on seed physiological potential of common bean varieties. Additionally, Toledo et al. (2009) found that the effects were still present after a four-month-storage.

In a more detailed analysis of first count of germination, accelerated aging and seedling length data, it was also possible to observe that the treatment with inoculated seeds plus topdressed $\mathrm{N}$ fertilization of 50 kg.ha ${ }^{-1}$ had equal results to $120 \mathrm{~kg} \cdot \mathrm{ha}^{-1} \mathrm{~N}$ fertilization. Pelegrin et al. (2009), using inoculated seeds in common beans with soil $\mathrm{N}$ fertilization of $20 \mathrm{~kg}^{-1}$, found similar results of grain yield when compared to noninoculated seeds fertilized with $160 \mathrm{~kg} \cdot \mathrm{ha}^{-1}$ of $\mathrm{N}$. The results also indicated that the plants received enough $\mathrm{N}$ during their cultivation cycle for keeping their production potential and seed quality.

\section{CONCLUSION}

$\mathrm{N}$ mineral fertilization could be reduced in common bean crops, from high $\left(120 \mathrm{~kg} \cdot \mathrm{ha}^{-1}\right)$ to low $\left(50 \mathrm{~kg} \cdot \mathrm{ha}^{-1}\right)$ doses when combined with rhizobium inoculation, for it does not affect seed physiological potential.

\section{REFERENCES}

AMBROSANO, E.J.; AMBROSANO, G.M.B.; WUTKE, E.B.; BULISANI, E.A.; MARTINS, A.L.M.; SILVEIRA, L.C.P. 1999. The effect of nitrogen and micronutrient on seed quality of dry 
beans - Carioca. Bragantia, Campinas, v.58, n.2, p.393-399.

ANDREWS, M.; HODGE, S.; RAVEN, J.A. 2010. Positive plant microbial reactions. Annals of Applied Biology, Malden, v.157, n.3, p.317-320.

BRASIL, 2009. Ministério da Agricultura, Pecuária e Abastecimento. Regras para análise de sementes. Brasília: MAPA/ACS, 399p.

CARVALHO, N.M.; NAKAGAWA, J. 2000. Sementes: ciência, tecnologia e produção. Jaboticabal: FUNEP, 588p.

CRUSCIOL, C.A.C.; LIMA, E.V.; ANDREOTTI, M.; NAKAGAWA, J.; LEMOS, L.B.; MARUBAYASHI, O.N. 2003. Nitrogen effect on the productivity, physiological quality and characteristics of dry bean seed. Journal of Seed Science, Pelotas, v.25, n.1, p.108-115.

FAGERIA, N.K.; BALIGAR, V.C.; JONES, C.A. 2011. Growth and mineral nutrition of field crops. $3^{\text {rd }}$ edition. Boca Raton, Florida: CRC Press, 586p.

FARINELLI, R.; LEMOS, L.B.; CAVARIANI, C.; NAKAGAWA, J. 2006. Productivity and physiological quality of common bean seeds in function of soil tillage systems and nitrogen fertilization. Journal of Seed

Science, Pelotas, v.28, n.2, p.102-109.

FUSTEC, J.; LESUFFLEUR, F.; MAHIEU, S.; CLIQUET, J.B. 2010. Nitrogen rhizodeposition of legumes. A review. Agronomy for Sustainable Development, Paris, v.30, n.1, p.57-66. GOMES-JÚNIOR, F.G.; SÁ, M.E. DE. 2010. Protein content and common bean (Phaseolus vulgaris L.) seed quality in relationship to nitrogen fertilization in a no-tillage system. Journal of Seed Science, Londrina, v.32, n.1, p.34-44.

HIREL, B.; TÉTU, T.; LEA, P.J.; DUBOIS, F. 2011. Improving nitrogen use efficiency in crops for sustainable agriculture. Sustainability, Basel, v.3, n.9, p.1452-1485.

HOODA, P.S.; EDWARDS, A.C.; ANDERSON, H.A.; MILLER, A., 2000. A review of water quality concerns in livestock farming areas. Science of the Total Environment, Philadelphia, v.250, n.2000, p.143-167.

KAPPES, C.; ARF, O.; FERREIRA, J.P.; PORTUGAL, J.R.; ALCALDE, A.M.; ARF, M.V.; VILELA, R.G. 2012. Physiological quality of seeds and growth of bean seedlings in relation to pre-harvest paraquat applications. 
Pesquisa Agropecuária Tropical,

Goiânia, v.42, n.1, p.9-18.

KIKUTI, H.; KIKUTI, A.L.P.; ANDRADE, M.J.B.; PEREIRA, C.E.; VON PINHO, E.V.R. 2007. Physiological potential of the bean seeds in function of nitrogen and phosphorus. Revista de Agricultura, Piracicaba, v.82, n.2, p.215-222.

LIU, Y.Y; WU, L.H.; BADDELEY, J.A.; WATSON, C.A. 2011. Models of biological nitrogen fixation of legumes. A review. Agronomy for Sustainable Development, Paris, v.31, 155-172.

PELEGRIN, R. DE; MERCANTE, F.M.; OTSUBO, I.M.N.; OTSUBO, A.A. 2009. Response of common bean crop to nitrogen fertilization and rhizobium inoculation. Revista Brasileira de Ciências do Solo, Viçosa, v.33, n.1, p.219-226.

TIKHONOVICH, I.A.; PROVOROV, N.A. 2011. Microbiology is the basis of sustainable agriculture: An opinion. Annals of Applied Biology, Malden, v.159, n.2, p.155-168.

TOLEDO, M.Z.; FONSECA, N.R.; CÉSAR, M.L.; SORATTO, R.P.; CAVARIANI, C.; CRUSCIOL， C.A.C. 2009. Physiological quality and storage of bean seeds as affected by late side dressing nitrogen. Pesquisa Agropecuária Tropical, Goiânia, v.39, n.2, p.124-133. ZUCARELI, C.; PRANDO, A.M.; RAMOSJÚNIOR, E.U.; NAKAGAWA, J. 2011. Phosphorus on the productivity and seed quality of bean Carioca Precoce cultivate during the rainy season. Revista Ciência Agronômica, Fortaleza, v.42, n.1, p.3238.

Recebido em: 11/11/2013 Aceito para publicação em: 7/08/2014 